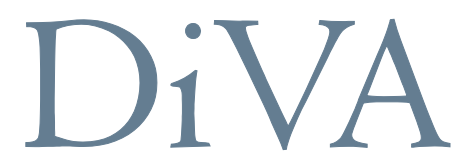

http://uu.diva-portal.org

This is an author produced version of a chapter published in Inositol Phosphates and Lipids: Methods and Protocols (ed. Christopher J.

Barker). This paper has been peer-reviewed but does not include the final publisher proof-corrections or journal pagination.

Citation for the published version:

Anne Wuttke, Olof Idevall-Hagren and Anders Tengholm "Imaging phosphoinositide dynamics in living cells" In: Inositol Phosphates and Lipids: Methods and Protocols, ed. Christopher J. Barker, 2010, pp. 219-235 (Methods in Molecular Biology, vol. 645)

URL: $\underline{\text { http://dx.doi.org/10.1007/978-1-60327-175-2 } 14}$

The original publication is available at www.springerlink.com (access may require subscription). 


\title{
Imaging phosphoinositide dynamics in living cells
}

\author{
Anne Wuttke, Olof Idevall-Hagren and Anders Tengholm \\ Department of Medical Cell Biology, Uppsala University, Biomedical Centre, Box 571, SE- \\ 75123 Uppsala, Sweden
}

Key words: phosphatidylinositol 4,5-bisphosphate, phosphatidylinositol 3,4,5-trisphosphate, phospholipase C, PI3-kinase, pleckstrin homology domain, $\mathrm{Ca}^{2+}$, green fluorescent protein, total internal reflection fluorescence microscopy, insulinsecreting cell

Correspondence:

Anders Tengholm, Ph.D.

Department of Medical Cell Biology

Uppsala University

Biomedical Centre, Box 571

SE-751 23 Uppsala

Sweden

Phone: +46-18-4714481

Fax: +46-18-4714059

E-mail: anders.tengholm@mcb.uu.se 


\section{Abstract}

To improve our understanding of the important roles played by inositol lipid derivatives in signalling and other cellular processes, it is crucial to measure phosphoinositide concentration changes in individual cells with high spatial and temporal resolution. A number of protein domains have been identified that interact with inositol lipids in a specific manner. Tagged with the green fluorescent protein or its colour variants, these protein modules can be used as probes to visualize various phosphoinositide species in different subcellular compartments. Here, we present protocols for fluorescence imaging of phosphoinositide dynamics in single living cells. Total internal reflection fluorescence microscopy is particularly powerful for time-lapse recordings of phosphoinositides in the plasma membrane. We demonstrate how this technique can be used to record phospholipase C- and PI3-kinase-induced changes in inositol lipids in insulin-secreting cells. These procedures should be applicable to studies of the spatio-temporal regulation of phosphoinositide metabolism in many types of cells.

\section{Introduction}

Given the crucial function of phosphoinositides (PIs) and inositol phosphates in many biological processes, it is essential to improve the understanding of their spatio-temporal regulation in various cells and tissues. Biochemical techniques based on radiotracer labelling, chromatography or mass spectrometry are of great value for investigating PI profiles in cell and tissue extracts. They yield quantitative information and can be optimized to distinguish between all different PI isomers (1). However, these methods have also important limitations; the major ones being that large numbers of cells are required to obtain a sufficient signal and that repeated measurements cannot be made from the same sample. These shortcomings 
preclude detection of compartmentalized signals, short-lasting transients, oscillations and other complex time-courses that characterize many signalling systems.

Over the past decade the development of genetically encoded fluorescence biosensors for single cell detection of PIs has greatly improved our understanding of PI lipid signalling. Pioneered by the Meyer (2) and Balla (3) laboratories, the use of green fluorescent protein (GFP) or its spectral variants fused to protein modules with specific PI binding properties has become the most valuable tool in the investigation of PIs in single living cells. Analysis of fluorescent reporter protein localization and stimulus-induced translocation provides information about the intracellular distribution and changes in relative levels of a particular lipid.

A large number of protein domains have been identified that are useful for following changes in a wide variety of intracellular lipids (4-7). A non-exhaustive list of such protein domains for detection of particular PI lipids in single cells is presented in Table 1. Fab1p-

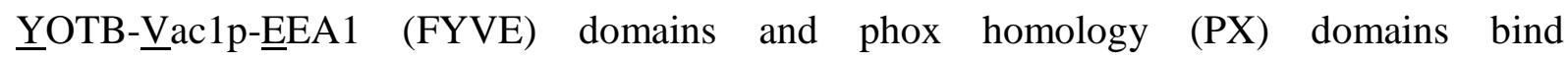
phosphatidylinositol-3-phosphate and perhaps other 3'-phosphorylated inositides. The pleckstrin homology $(\mathrm{PH})$ domains constitute the largest family of PI-binding protein modules and are the most commonly employed probes in imaging studies. The availability of fairly extensive information on in vitro binding specificity probably contributes to their popularity in imaging applications. Most PH domains bind membrane PIs with low affinity and little specificity (5), but there are $\mathrm{PH}$ domains with relatively high affinity and specificity for most of the 4'- and 5'-phosphorylated PI lipids.

The $\mathrm{PH}$ domain from phospholipase $\mathrm{C}-\delta 1\left(\mathrm{PH}_{\mathrm{PLC} \delta 1}\right)$ is the best characterized PI-binding protein domain. It binds strongly in vitro to phosphatidylinositol-4,5-bisphosphate $\left(\operatorname{PtdIns}(4,5) P_{2}\right)$ and with even higher affinity to its isolated headgroup D-myo-inositol-1,4,5trisphosphate $\left(\operatorname{Ins} P_{3}\right)(8)$, and is therefore a valuable tool for assessing $\operatorname{PtdIns}(4,5) P_{2}$ 
localization and phospholipase C (PLC) activity in individual cells. In unstimulated cells, the GFP-tagged $\mathrm{PH}_{\mathrm{PLC} \delta 1}$ is bound to the plasma membrane, where the concentration of $\operatorname{PtdIns}(4,5) P_{2}$ is relatively high. Upon activation of PLC, which hydrolyzes $\operatorname{PtdIns}(4,5) P_{2}$ into $\operatorname{Ins} P_{3}$ and diacylglycerol, the biosensor dissociates from the membrane and binds $\operatorname{Ins} P_{3}$ in the cytoplasm (Fig. 1A). Additional examples of PH domains with high PI binding specificity include those from protein kinase B/Akt and GRP1 (general receptor for phosphoinositides1), which have been extensively used for detecting phosphatidylinositol-3,4-bisphosphate $\left(\operatorname{PtdIns}(3,4) P_{2}\right)$ and phosphatidylinositol-3,4,5-trisphosphate $\left(\operatorname{Ptd} \operatorname{Ins}(3,4,5) P_{3}\right) \quad(9-11)$, the lipid products of phosphoinositide-3-OH-kinase (PI3-kinase) activity. As the concentration of PtdIns(3,4) $P_{2}$ and PtdIns $(3,4,5) P_{3}$ is very low in unstimulated cells, fluorescent protein-tagged versions of these PH domains are distributed in the cytoplasm and nucleus. Receptor stimuli which activate PI3-kinase cause translocation of the biosensors to the plasma membrane (Fig. 1B). For more detailed information on the different PI-binding protein modules, the reader is referred to the references in Table 1 and to recent comprehensive reviews $(4-7,12,13)$.

The localization of the fluorescent biosensors is most commonly analyzed with confocal microscopy, which provides high resolution images of optical sections of the specimen. This technique is well suited for visualization of different subcellular compartments, such as the plasma membrane, cytoplasm and intracellular organelles. For cell types that are very flat, regular wide-field epifluorescence microscopy might work equally well. In many cases, the interesting changes in PI lipids take place in the plasma membrane. A technique known as evanescent wave microscopy or total internal reflection fluorescence (TIRF) microscopy, provides selective imaging of fluorescence in a thin volume of the cell where the plasma membrane is in contact with the coverslip $(\mathbf{1 4 , 1 5 )}$. In this method a laser beam is directed towards a coverslip with adhering cells at an angle causing total reflection at the interface between the coverslip and the lower refractive index aqueous medium surrounding the cells. 
Excitation is provided by an evanescent wave travelling in a zone within $\sim 100 \mathrm{~nm}$ above the glass-water interface, exciting fluorescent molecules exclusively in the plasma membrane and the immediate sub-membrane space (Fig. 1C). Studies in the authors' laboratory have employed TIRF microscopy for measurements of the plasma membrane $\operatorname{Ptd} \operatorname{Ins}(4,5) P_{2}$ and PtdIns $(3,4,5) P_{3}$ concentrations using the $\mathrm{PH}$ domains from PLC $\delta 1$ and protein kinase B/Akt (16-19). TIRF microscopy provides better resolution as the optical section is several-fold thinner than in confocal microscopy. Since most of the sample is not illuminated, there is little background, which provides better signal-to-noise ratio and thereby increased sensitivity to detect small fluorescence changes. Moreover, photobleaching and phototoxicity are greatly reduced, which permits measurements over longer periods of time and with better time resolution without damaging the specimen. Another major advantage of TIRF microscopy is that the detection of biosensor translocation to or from the plasma membrane only requires simple fluorescence intensity recordings, which can be made on many cells in parallel (Fig. 1D).

Several excellent reviews have been published on single cell imaging of phosphoinositides and advantages and limitations of this approach $(4,6,13)$. Here, we detail the procedures used in our laboratory for time-lapse image analysis of PI levels in the plasma membrane of individual living cells. Although particular emphasis is made on TIRF microscopy recordings of phospholipase C- and PI3-kinase-induced changes in $\operatorname{Ptd} \operatorname{Ins}(4,5) P_{2}$ and $\operatorname{Ptd} \operatorname{Ins}(3,4,5) P_{3}$ in insulin-secreting cells, the protocols should be generally applicable to other cell types and signalling pathways. In many cases it is important to study the relationship between the changes in PI lipids and other signalling events. As an example, we have included a description of parallel recordings of lipid signals and the cytoplasmic $\mathrm{Ca}^{2+}$ concentration. 


\section{Materials}

\subsection{Cell culture and transfection}

1. Glass cover slips, 25-mm diameter, 0.08-0.13 mm thickness (from e.g. Menzel-Gläser, Germany).

2. Poly-L-lysine (MW 70,000-150,000, Sigma, St Louis, MO): Prepare $0.1 \mathrm{mg} / \mathrm{mL}$ stock solution in sterile water and store at $-20^{\circ} \mathrm{C}$. Prepare the working solution at a concentration of $0.01 \mathrm{mg} / \mathrm{mL}$ in sterile water.

3. Dulbecco's phosphate buffered saline (D-PBS, Invitrogen, Carlsbad, CA): $137 \mathrm{mM} \mathrm{NaCl}$, $2.67 \mathrm{mM} \mathrm{KCl}, 8.10 \mathrm{mM} \mathrm{Na}_{2} \mathrm{HPO}_{4}, 1.47 \mathrm{mM} \mathrm{KH}_{2} \mathrm{PO}_{4}$, store at $+4{ }^{\circ} \mathrm{C}$.

4. Complete growth medium for MIN6 $\beta$-cells is prepared from Dulbecco's Modified Eagle's Medium (DMEM) containing $4500 \mathrm{mg} / \mathrm{L}$ glucose (Invitrogen) by supplementing with $15 \%$ (v/v) fetal calf serum, $2 \mathrm{mM}$ L-glutamine, $70 \mu \mathrm{M} \beta$-mercaptoethanol, $100 \mathrm{U} / \mathrm{mL}$ penicillin and $100 \mu \mathrm{g} / \mathrm{mL}$ streptomycin. Store at $+4{ }^{\circ} \mathrm{C}$.

5. For transient transfection of MIN6 cells, use Lipofectamine ${ }^{\mathrm{TM}} 2000$ reagent (Invitrogen) and OptiMEM I (Invitrogen). The Lipofectamine ${ }^{\mathrm{TM}} 2000$ reagent should be mixed gently before use. Store at $+4{ }^{\circ} \mathrm{C}$.

6. Plasmid DNA encoding the PI biosensor of interest. 
7. Fura Red acetoxymethyl ester (Molecular Probes Invitrogen) for measurements of the cytoplasmic $\mathrm{Ca}^{2+}$ concentration.

\subsection{Fluorescence microscopy}

1. Experimental buffer for incubation and superfusion: $125 \mathrm{mM} \mathrm{NaCl}, 4.9 \mathrm{mM} \mathrm{KCl}, 1.3$ $\mathrm{mM} \mathrm{CaCl} 2,1.2 \mathrm{mM} \mathrm{MgCl} 2,25 \mathrm{mM}$ HEPES, $3 \mathrm{mM}$ D-glucose and $0.1 \%$ (w/v) bovine serum albumin. Adjust $\mathrm{pH}$ with $\mathrm{NaOH}$ to 7.40 at $37^{\circ} \mathrm{C}$. This buffer is made fresh on the day of experiment.

2. Confocal or TIRF fluorescence microscope: While a regular fluorescence microscope may occasionally work for some very flat cell types, a microscope with optical sectioning capability is advantageous in the majority of cases. Confocal microscopy is required for analysis of PI lipids in intracellular organelles, whereas TIRF is better for imaging the plasma membrane.

a. Many suitable confocal systems are available through the major microscope manufacturers. The authors use a Yokogawa CSU-10 spinning disk system (available from several distributors in Europe and the US), well suited for live cell imaging in permitting a high acquisition speed and yet relatively low degree of photobleaching.

b. TIRF illumination can easily be obtained through the objective lens using a high NA (>1.40) objective and an illuminator device for beam focussing and positioning (available from many of the major microscope manufacturers; illuminator also available from TILL Photonics / Agilent Technology, Santa Clara, CA). An alternative TIRF configuration uses a prism for illumination, which has the advantage of allowing imaging with a low magnification objective to obtain information from many cells in 
parallel (Fig. 1D). The authors use a custom-built system, but commercial illuminators are available from e.g. TIRF Technologies (Morrisville, NC).

3. Light source, filters for wavelength selection, and equipment for image acquisition and analysis: Commercial confocal microscope systems are usually equipped with all required peripheral instrumentation. A TIRF system often requires custom configuration.

a. The argon ion laser is a common light source for excitation of fluorescent proteins. GFP is excited with the 488-nm line and the 458-nm and 514-nm lines can be used for excitation of cyan and yellow fluorescent protein and even of some red fluorescent proteins. Solid state lasers are becoming increasingly popular and are available in a variety of spectral variants well suited for imaging GFP and related fluorescent proteins.

b. Appropriate excitation filter (e.g. $488 \mathrm{~nm} / 10 \mathrm{~nm}$ half-bandwidth), dichroic mirror (e.g. 500DCXRU) and emission filters (e.g. 525/40 nm for GFP and $630 \mathrm{~nm}$ long-pass for Fura Red) can be obtained from Chroma Technology (Rockingham, VT), Omega Optical (Battleboro, VT) or Semrock (Rochester, NY). Dual channel recordings may require a filter changer, which can be obtained from e.g. Sutter Instruments (Novato, CA).

c. A sensitive low-light level charge-coupled device (CCD) camera for spinning disk confocal or TIRF microscope can be obtained from e.g. Andor Technology, Hamamatsu, Princeton Instruments and Cooke corporation.

d. Data acquisition and analysis software are usually included with commercial confocal systems, but may have to be purchased separately for custom-built setups. The authors use MetaFluor from Molecular Devices (Downington, PA) and the free ImageJ 
software (Rasband, W.S., National Institutes of Health, Bethesda, MD, http://rsb.info.nih.gov/ij/).

4. Equipment for buffer superfusion and thermoregulation: It is often important to be able to add and remove test substances as well as to maintain a temperature of $37^{\circ} \mathrm{C}$ during the experiment. We use a peristaltic pump in combination with a custom-built superfusion chamber, chamber heater and microscope objective heater. Similar equipment is available from e.g. Warner Instruments (Hamden, CT).

\section{Methods}

\subsection{Preparation of poly-L-lysine coated coverslips}

1. Wash the coverslips in deionized water and sterilize in a heat incubator $\left(180{ }^{\circ} \mathrm{C}\right)$ or by dipping them into 95\% ethanol and passing through the flame of a Bunsen burner. Place each sterile coverslip in a $35 \mathrm{~mm}$ diameter culture dish.

2. Place a $\sim 100 \mu \mathrm{L}$ drop of poly-L-lysine $(0.01 \mathrm{mg} / \mathrm{mL})$ on the coverslip, leave it for $20-30$ min at room temperature and then remove the poly-L-lysine and rinse the coverslip twice with sterile water. It is important not to let the poly-L-lysine dry on the coverslips. After the last washing step, remove as much water as possible and allow the coverslips to dry in a laminar flow bench with the lids of the culture dishes open (see Note 1).

\subsection{Cell culture and transient transfection}

1. Seed cells onto the dried poly-L-lysine coated coverslips by adding $3 \mathrm{~mL}$ cell suspension at a concentration of $0.1-0.2 \times 10^{6} / \mathrm{mL}$. The confluency should be approximately $50 \%$ on the day of transfection (see Note 2). 
2. For each coverslip to be transfected, mix $2 \mu \mathrm{g}$ of plasmid DNA encoding the PI biosensor of interest with $125 \mu \mathrm{L}$ OptiMEM I in one tube and $5 \mu \mathrm{L}$ Lipofectamine ${ }^{\mathrm{TM}} 2000$ with $125 \mu \mathrm{L}$ OptiMEM I in another tube. Leave the tubes for $5 \mathrm{~min}$ at room temperature (see Note 3).

3. Combine the content of the two tubes and mix gently (do not vortex). Leave for $20 \mathrm{~min}$ at room temperature to allow DNA-liposome complexes to form.

4. Remove complete culture medium from the cells and carefully rinse them once with D-PBS preheated to $37^{\circ} \mathrm{C}$.

5. Remove the D-PBS and add to each cover slip $750 \mu \mathrm{L}$ OptiMEM I conditioned to $37{ }^{\circ} \mathrm{C}$. Subsequently add the DNA-liposome combination $(\sim 250 \mu \mathrm{L}$ per cover slip) and mix by gently rocking the culture dish back and forth.

6. Incubate the cells for $3-5 \mathrm{~h}$ at $37{ }^{\circ} \mathrm{C}$ and $5 \% \mathrm{CO}_{2}$ in a cell culture incubator.

7. Terminate the transfection reaction by removing the transfection medium, rinsing the cells once with D-PBS at $37^{\circ} \mathrm{C}$ and adding $3 \mathrm{~mL}$ complete growth medium.

8. Culture the transfected cells for $12-48 \mathrm{~h}$ before imaging experiments to allow expression of the PI biosensor (see Note 4). 


\subsection{Time-lapse imaging of phosphoinositide dynamics in living cells}

1. Rinse the cells on the cover slip once with the experimental buffer, add $2 \mathrm{~mL}$ new buffer to the dish and incubate for $30-60 \mathrm{~min}$ in a $37{ }^{\circ} \mathrm{C}$ incubator to allow cells to adapt to basal conditions in the experimental buffer (see Note 5).

2. Place the cover slip with cells in a suitable superfusion chamber that fits the stage of the microscope.

3. Place the chamber on the thermostated microscope stage, connect the chamber to a peristaltic pump and superfuse cells with the experimental buffer at a rate of $0.5-1 \mathrm{~mL} / \mathrm{min}$. The speed should be such that the entire chamber volume is exchanged several times per minute. Make sure that the temperature is $37^{\circ} \mathrm{C}$ in the chamber (see Note 6).

4. Observe the transfected cells in the fluorescence microscope with appropriate settings for fluorescent protein excitation and emission and select a region of the coverslip with cells expressing moderate levels of the PI biosensor. (see Note 7).

5. Project the image on the CCD camera and adjust acquisition parameters, such as exposure time and signal gain to appropriate levels. (see Note 8)

6. Move stage to find a region on the cover slip without cells. Acquire a background image without changing imaging parameters. Return to the previously identified cover slip region with the cells.

7. Acquire images with the CCD camera every $1-5 \mathrm{~s}$. 
8. Analyze changes of relative fluorescence in individual cells. Most software permits plotting of intensity changes on-line to help monitoring the experiment, but in addition a more careful off-line analysis is required. Subtract the background image and plot fluorescence from regions of interest using suitable software (e.g. MetaMorph or MetaFluor from Molecular Devices, or ImageJ, W.S.Rasband, rsb.info.nih.gov/ij). Different analysis strategies are required depending on the type of images (see Fig. 2 and Note 9).

\subsection{Simultaneous recordings of cytoplasmic $\mathrm{Ca}^{2+}$ concentration and phosphoinositide dynamics in living cells}

1. Rinse the transfected cells twice with experimental buffer, add $2 \mathrm{~mL}$ of the buffer supplemented with $10 \mu \mathrm{M}$ of the acetoxymethyl ester of the $\mathrm{Ca}^{2+}$ indicator Fura Red and incubate for $45 \mathrm{~min}$ at $37^{\circ} \mathrm{C}$ and protect from light. (see Note 10).

2. Rinse the cells thoroughly with experimental buffer to remove extracellular indicator.

3. Mount the cover slip in the microscope superfusion chamber and record fluorescence as described in section 3.3 (see Fig. 3 and Note 11). 


\section{Notes}

1. As an alternative to poly-L-lysine, cover slips can be coated with collagen, fibronectin or gelatine. For gelatine coating, add $1 \%(\mathrm{w} / \mathrm{v})$ sterile gelatine in D-PBS to the cover slips, incubate for $1 \mathrm{~h}$ in a cell culture incubator at $37^{\circ} \mathrm{C}$ in a humidified atmosphere, remove the gelatine and wash twice with D-PBS. Seed cells onto the cover slips immediately, because the gelatine must not dry.

2. This protocol typically yields 30-40\% transfection efficiency 1-2 days after transfection. The best results are obtained if the cells are allowed to grow on the cover slip for 36-48 hours prior to transfection. The protocol is optimized for insulin-secreting MIN6 and INS-1 cells, and may have to be modified for other cell lines. Obviously, other methods for transfection can be used. For example, adenovirus-mediated gene transfer is highly efficient in a large variety of cell types.

3. If the experiment requires transfection of more than one plasmid, all cDNA should be transfected at the same time to obtain maximal cotransfection. It is not recommended to use more than a total of $3 \mu \mathrm{g}$ plasmid DNA per coverslip as higher concentrations may have adverse effects on the cells and contribute to reduction of the transfection efficiency. Adjust the volume of liposomes when changing the amount of DNA to maintain the ratio of DNA:Lipofectamine 2000 at 1:2.5 (w/v).

4. Do not allow cells to express the biosensor protein for more than $48 \mathrm{~h}$, since excessive levels of the fusion protein may affect cell function. This is because the PI-binding fluorescent proteins will compete for endogenous effectors, which potentially inhibits the lipid-mediated cellular responses $(\mathbf{1 3})$. 
5. For some cell types and applications longer pre-incubation time in serum-free culture medium may be required (up to several hours), since serum contains factors that may e.g. stimulate PI3-kinase formation of $\operatorname{PtdIns}(3,4,5) P_{3}$.

6. Although cells can be stimulated by adding medium into the bath with a pipette, it is preferable to add medium using a superfusion system. Such a system not only permits convenient washout of the stimulus, but also eliminates problems with evaporation that otherwise would occur, since the ambient temperature should be maintained at $37{ }^{\circ} \mathrm{C}$ to observe normal biosensor localization and translocation responses.

7. There will be cells expressing the fluorescent biosensors over a wide range of expression levels. High levels of phosphoinositide binding proteins can interfere with processes in the cells as mentioned in Note 4. Choose cells with relatively low expression levels, but not so low that the signal-to-noise ratio is compromised. The fluorescence collected from the cells expressing the biosensor should be well above the autofluorescence from non-transfected cells. Also avoid cells with large fluorescent aggregates, as this often reflects accumulation of improperly folded proteins in the endoplasmic reticulum or Golgi apparatus.

8. Select camera exposure time and gain settings so that no pixels in the image will be saturated. It is important to consider that the fluorescence intensity might change several-fold during an experiment if the biosensor redistributes between different cellular compartments. It is good to keep the exposure times as short as possible without compromising signal-to-noise ratio, since excessive exposure to excitation light may result in photobleaching and phototoxic effects. If the fluorescence collected from the cells is very low, it is possible with most CCD 
cameras to combine charges in adjacent pixels to form one pixel in a process named binning. This will enhance the signal at the expense of optical resolution. On the contrary, if the signal is too bright, it indicates an excessive excitation light intensity. Reduce the laser power or attenuate the light with neutral density filters in the excitation beam path. The laser beam should be completely blocked with a shutter between image captures to avoid adverse effects of the light on the specimen.

9. a. For confocal microscopy images, the simplest way to assess plasma membrane translocation and dissociation of the biosensor is to quantify the changes in cytoplasmic fluorescence by defining a region of interest inside the cell that excludes the nucleus, membrane or other conspicuous organelles. Alternatively, regions of interest can be placed over the plasma membrane either manually or with the help of a segmentation algorithm. This is often a difficult method because the cell shape tends to change over the time-course of an experiment, in particular after cell stimulation.

b. In TIRF microscopy images, a region of interest over the cell will always show fluorescence in the plasma membrane and translocation or dissociation is simply recorded as changes of intensity.

c. Intensity changes can easily be expressed in relation to baseline by dividing the intensity value at each time point with the prestimulatory level $\left(\mathrm{F} / \mathrm{F}_{0}\right)$.

d. Some cell types exhibit profound membrane ruffling or other morphological changes, which can alter the area of membrane contact with the coverslip, especially after stimulation. In a TIRF microscope such morphological changes can induce a fluorescence change that might be misinterpreted as translocation. It is therefore important to perform control experiments to ensure that an observed fluorescence change is indeed due to biosensor translocation. The translocation response can be 
confirmed with confocal microscopy. An alternative and more powerful approach is to use a reference fluorescent protein that remains soluble in the cytoplasm or attached to the plasma membrane. Ideally, such an experiment should be performed by coexpressing the PI biosensor tagged with one fluorescent protein and the reference protein in a different colour to enable simultaneous recordings of the two constructs in the same cell (Fig. 2).

e. As an alternative to translocation readout, some PI-binding protein domains have been used in biosensors that rely on fluorescence resonance energy transfer between cyan and yellow fluorescent proteins as a result of a conformational change in the protein domain upon lipid binding $(\mathbf{2 0 , 2 1})$. However, proper detection of fluorescence resonance energy transfer is technically difficult and the dynamic range of the signals is typically much smaller than for the translocation-based biosensors.

f. It is important to keep in mind that a certain PI-binding protein domain often does not recognize all pools of the particular lipid because of competition with endogenous effectors binding to the lipid. For example, the $\mathrm{PH}_{\mathrm{PLC} \delta 1}$ recognizes $\operatorname{PtdIns}(4,5) P_{2}$ exclusively in the plasma membrane, although the lipid is known to occur also in intracellular membranes. In addition, the localization of the PI-binding protein domains is not only determined by binding to lipids, but may also be affected by interactions with other proteins. See reference (13) for a more thorough discussion on these limitations.

10. Dissolve Fura Red at $10 \mathrm{mM}$ in DMSO and store at $-20^{\circ} \mathrm{C}$ protected from light. Mix before use and incubate together with cells at 2-20 $\mu \mathrm{M}$ during 20-45 minutes. The optimal indicator concentrations and incubation times vary depending on cell type and cell density. Excessive loading may reduce the $\mathrm{Ca}^{2+}$ response by buffering the concentration changes, whereas too little loading gives poor signal-to-noise ratio. 
11. Fura Red is readily excited by the same light source as GFP, such as the 488-nm line of the argon ion laser. Fluorescence emission is detected with a $630 \mathrm{~nm}$ long-pass filter. Upon $\mathrm{Ca}^{2+}$ binding, the excitation spectrum of Fura Red becomes blue-shifted resulting in loss of $488 \mathrm{~nm}$ excited fluorescence. With appropriate emission filters, the fluorescence from Fura Red can be well separated from that of GFP-labelled PI biosensors. Alternation between the Fura Red and GFP emission filters using a filter wheel or similar device allows simultaneous measurements of cytoplasmic $\mathrm{Ca}^{2+}$ concentration and PI lipid dynamics in the same cell. However, as GFP shows some emission even above $600 \mathrm{~nm}$, there may be a slight cross-over of GFP fluorescence into the Fura Red channel in cells with very bright GFP fluorescence and poor Fura Red loading. The degree of overlap is easily estimated by imaging cells expressing GFP, but lacking the $\mathrm{Ca}^{2+}$ indicator, using the Fura Red filter set.

\section{Acknowledgements}

We thank Professors Tobias Meyer, Stanford University, for the GFP-PH $\mathrm{Akt}_{\text {and }} \mathrm{PH}_{\mathrm{PLC} \delta 1}-\mathrm{GFP}$ plasmids and Roger Tsien, University of California in San Diego, for tdimer2. The authors' work is supported by grants from Åke Wiberg's Foundation, the European Foundation for the Study of Diabetes/MSD, the family Ernfors Foundation, Harald and Greta Jeanssons Foundations, Novo Nordisk Foundation, the Swedish Diabetes Association and the Swedish Research Council. 


\section{References}

1. Rusten, T. E., and Stenmark, H. (2006) Analyzing phosphoinositides and their interacting proteins. Nat Methods 3, 251-258.

2. Stauffer, T. P., Ahn, S., and Meyer, T. (1998) Receptor-induced transient reduction in plasma membrane PtdIns $(4,5) \mathrm{P}_{2}$ concentration monitored in living cells. Curr Biol 8, 343-346.

3. Varnai, P., and Balla, T. (1998) Visualization of phosphoinositides that bind pleckstrin homology domains: calcium- and agonist-induced dynamic changes and relationship to myo- $\left.{ }^{3} \mathrm{H}\right]$ inositol-labeled phosphoinositide pools. J Cell Biol 143, 501-510.

4. Halet, G. (2005) Imaging phosphoinositide dynamics using GFP-tagged protein domains. Biol Cell 97, 501-518.

5. Lemmon, M. A. (2008) Membrane recognition by phospholipid-binding domains. Nat Rev Mol Cell Biol 9, 99-111.

6. Balla, T., and Varnai, P. (2002) Visualizing cellular phosphoinositide pools with GFPfused protein-modules. Sci STKE 2002, PL3.

7. Lemmon, M. A. (2003) Phosphoinositide recognition domains. Traffic 4, 201-213.

8. Lemmon, M. A., Ferguson, K. M., O'Brien, R., Sigler, P. B., and Schlessinger, J. (1995) Specific and high-affinity binding of inositol phosphates to an isolated pleckstrin homology domain. Proc Natl Acad Sci U S A 92, 10472-10476.

9. Haugh, J. M., Codazzi, F., Teruel, M., and Meyer, T. (2000) Spatial sensing in fibroblasts mediated by 3' phosphoinositides. J Cell Biol 151, 1269-1280.

10. Gray, A., Van Der Kaay, J., and Downes, C. P. (1999) The pleckstrin homology domains of protein kinase B and GRP1 (general receptor for phosphoinositides-1) are sensitive and selective probes for the cellular detection of phosphatidylinositol 3,4bisphosphate and/or phosphatidylinositol 3,4,5-trisphosphate in vivo. Biochem J 344 Pt 3, 929-936.

11. Tengholm, A., and Meyer, T. (2002) A PI3-kinase signaling code for insulin-triggered insertion of glucose transporters into the plasma membrane. Curr Biol 12, 1871-1876.

12. Downes, C. P., Gray, A., and Lucocq, J. M. (2005) Probing phosphoinositide functions in signaling and membrane trafficking. Trends Cell Biol 15, 259-268.

13. Varnai, P., and Balla, T. (2006) Live cell imaging of phosphoinositide dynamics with fluorescent protein domains. Biochim Biophys Acta 1761, 957-967.

14. Axelrod, D. (2001) Total internal reflection fluorescence microscopy in cell biology. Traffic 2, 764-774.

15. Steyer, J. A., and Almers, W. (2001) A real-time view of life within $100 \mathrm{~nm}$ of the plasma membrane. Nat Rev Mol Cell Biol 2, 268-275.

16. Thore, S., Dyachok, O., and Tengholm, A. (2004) Oscillations of phospholipase C activity triggered by depolarization and $\mathrm{Ca}^{2+}$ influx in insulin-secreting cells. $\mathrm{J}$ Biol Chem 279, 19396-19400.

17. Thore, S., Dyachok, O., Gylfe, E., and Tengholm, A. (2005) Feedback activation of phospholipase $\mathrm{C}$ via intracellular mobilization and store-operated influx of $\mathrm{Ca}^{2+}$ in insulin-secreting $\beta$-cells. J Cell Sci 118, 4463-4471.

18. Thore, S., Wuttke, A., and Tengholm, A. (2007) Rapid turnover of phosphatidylinositol-4,5-bisphosphate in insulin-secreting cells mediated by $\mathrm{Ca}^{2+}$ and the ATP-to-ADP ratio. Diabetes 56, 818-826. 
19. Idevall-Hagren, O., and Tengholm, A. (2006) Glucose and insulin synergistically activate PI3-kinase to trigger oscillations of phosphatidylinositol-3,4,5-trisphosphate in beta -cells. J Biol Chem 281, 39121-39127.

20. Sato, M., Ueda, Y., Takagi, T., and Umezawa, Y. (2003) Production of PtdInsP3 at endomembranes is triggered by receptor endocytosis. Nat Cell Biol 5, 1016-1022.

21. Ananthanarayanan, B., Ni, Q., and Zhang, J. (2005) Signal propagation from membrane messengers to nuclear effectors revealed by reporters of phosphoinositide dynamics and Akt activity. Proc Natl Acad Sci U S A 102, 15081-15086.

22. Gillooly, D. J., Morrow, I. C., Lindsay, M., Gould, R., Bryant, N. J., Gaullier, J. M., Parton, R. G., and Stenmark, H. (2000) Localization of phosphatidylinositol 3phosphate in yeast and mammalian cells. Embo J 19, 4577-4588.

23. Burd, C. G., and Emr, S. D. (1998) Phosphatidylinositol(3)-phosphate signaling mediated by specific binding to RING FYVE domains. Mol Cell 2, 157-162.

24. Gaullier, J. M., Simonsen, A., D'Arrigo, A., Bremnes, B., Stenmark, H., and Aasland, R. (1998) FYVE fingers bind PtdIns(3)P. Nature 394, 432-433.

25. Patki, V., Lawe, D. C., Corvera, S., Virbasius, J. V., and Chawla, A. (1998) A functional PtdIns(3)P-binding motif. Nature 394, 433-434.

26. Vermeer, J. E., van Leeuwen, W., Tobena-Santamaria, R., Laxalt, A. M., Jones, D. R., Divecha, N., Gadella, T. W., Jr., and Munnik, T. (2006) Visualization of PtdIns3P dynamics in living plant cells. Plant J 47, 687-700.

27. Stahelin, R. V., Burian, A., Bruzik, K. S., Murray, D., and Cho, W. (2003) Membrane binding mechanisms of the PX domains of NADPH oxidase p40phox and p47phox. $J$ Biol Chem 278, 14469-14479.

28. Ellson, C. D., Gobert-Gosse, S., Anderson, K. E., Davidson, K., Erdjument-Bromage, H., Tempst, P., Thuring, J. W., Cooper, M. A., Lim, Z. Y., Holmes, A. B., Gaffney, P. R., Coadwell, J., Chilvers, E. R., Hawkins, P. T., and Stephens, L. R. (2001) PtdIns(3)P regulates the neutrophil oxidase complex by binding to the PX domain of p40(phox). Nat Cell Biol 3, 679-682.

29. Ellson, C. D., Anderson, K. E., Morgan, G., Chilvers, E. R., Lipp, P., Stephens, L. R., and Hawkins, P. T. (2001) Phosphatidylinositol 3-phosphate is generated in phagosomal membranes. Curr Biol 11, 1631-1635.

30. Kanai, F., Liu, H., Field, S. J., Akbary, H., Matsuo, T., Brown, G. E., Cantley, L. C., and Yaffe, M. B. (2001) The PX domains of p47phox and p40phox bind to lipid products of PI(3)K. Nat Cell Biol 3, 675-678.

31. Levine, T. P., and Munro, S. (1998) The pleckstrin homology domain of oxysterolbinding protein recognises a determinant specific to Golgi membranes. Curr Biol 8, 729-739.

32. Levine, T. P., and Munro, S. (2002) Targeting of Golgi-specific pleckstrin homology domains involves both PtdIns 4-kinase-dependent and -independent components. Curr Biol 12, 695-704.

33. Balla, A., Tuymetova, G., Tsiomenko, A., Varnai, P., and Balla, T. (2005) A plasma membrane pool of phosphatidylinositol 4-phosphate is generated by phosphatidylinositol 4-kinase type-III alpha: studies with the $\mathrm{PH}$ domains of the oxysterol binding protein and FAPP1. Mol Biol Cell 16, 1282-1295.

34. Godi, A., Di Campli, A., Konstantakopoulos, A., Di Tullio, G., Alessi, D. R., Kular, G. S., Daniele, T., Marra, P., Lucocq, J. M., and De Matteis, M. A. (2004) FAPPs control Golgi-to-cell-surface membrane traffic by binding to ARF and PtdIns(4)P. Nat Cell Biol 6, 393-404.

35. Balla, A., Kim, Y. J., Varnai, P., Szentpetery, Z., Knight, Z., Shokat, K. M., and Balla, T. (2008) Maintenance of Hormone-sensitive Phosphoinositide Pools in the Plasma 
Membrane Requires Phosphatidylinositol 4-Kinase III \{alpha\}. Mol Biol Cell 19, 711721.

36. Roy, A., and Levine, T. P. (2004) Multiple pools of phosphatidylinositol 4-phosphate detected using the pleckstrin homology domain of Osh2p. J Biol Chem 279, 4468344689.

37. Gozani, O., Karuman, P., Jones, D. R., Ivanov, D., Cha, J., Lugovskoy, A. A., Baird, C. L., Zhu, H., Field, S. J., Lessnick, S. L., Villasenor, J., Mehrotra, B., Chen, J., Rao, V. R., Brugge, J. S., Ferguson, C. G., Payrastre, B., Myszka, D. G., Cantley, L. C., Wagner, G., Divecha, N., Prestwich, G. D., and Yuan, J. (2003) The PHD finger of the chromatin-associated protein ING2 functions as a nuclear phosphoinositide receptor. Cell 114, 99-111.

38. Karathanassis, D., Stahelin, R. V., Bravo, J., Perisic, O., Pacold, C. M., Cho, W., and Williams, R. L. (2002) Binding of the PX domain of p47(phox) to phosphatidylinositol 3,4-bisphosphate and phosphatidic acid is masked by an intramolecular interaction. Embo J 21, 5057-5068.

39. Zhan, Y., Virbasius, J. V., Song, X., Pomerleau, D. P., and Zhou, G. W. (2002) The p40phox and p47phox PX domains of NADPH oxidase target cell membranes via direct and indirect recruitment by phosphoinositides. J Biol Chem 277, 4512-4518.

40. Dowler, S., Currie, R. A., Campbell, D. G., Deak, M., Kular, G., Downes, C. P., and Alessi, D. R. (2000) Identification of pleckstrin-homology-domain-containing proteins with novel phosphoinositide-binding specificities. Biochem J 351, 19-31.

41. Manna, D., Albanese, A., Park, W. S., and Cho, W. (2007) Mechanistic basis of differential cellular responses of phosphatidylinositol 3,4-bisphosphate- and phosphatidylinositol 3,4,5-trisphosphate-binding pleckstrin homology domains. J Biol Chem 282, 32093-32105.

42. Kimber, W. A., Trinkle-Mulcahy, L., Cheung, P. C., Deak, M., Marsden, L. J., Kieloch, A., Watt, S., Javier, R. T., Gray, A., Downes, C. P., Lucocq, J. M., and Alessi, D. R. (2002) Evidence that the tandem-pleckstrin-homology-domaincontaining protein TAPP1 interacts with $\operatorname{Ptd}(3,4) \mathrm{P} 2$ and the multi-PDZ-domaincontaining protein MUPP1 in vivo. Biochem J 361, 525-536.

43. Xu, C., Watras, J., and Loew, L. M. (2003) Kinetic analysis of receptor-activated phosphoinositide turnover. J Cell Biol 161, 779-791.

44. Sun, Y., Carroll, S., Kaksonen, M., Toshima, J. Y., and Drubin, D. G. (2007) PtdIns(4,5) $\mathrm{P}_{2}$ turnover is required for multiple stages during clathrin- and actindependent endocytic internalization. J Cell Biol 177, 355-367.

45. Dove, S. K., Piper, R. C., McEwen, R. K., Yu, J. W., King, M. C., Hughes, D. C., Thuring, J., Holmes, A. B., Cooke, F. T., Michell, R. H., Parker, P. J., and Lemmon, M. A. (2004) Svp1p defines a family of phosphatidylinositol 3,5-bisphosphate effectors. Embo J 23, 1922-1933.

46. Krick, R., Tolstrup, J., Appelles, A., Henke, S., and Thumm, M. (2006) The relevance of the phosphatidylinositolphosphat-binding motif FRRGT of Atg18 and Atg21 for the Cvt pathway and autophagy. FEBS Lett 580, 4632-4638.

47. Yan, J., Wen, W., Xu, W., Long, J. F., Adams, M. E., Froehner, S. C., and Zhang, M. (2005) Structure of the split PH domain and distinct lipid-binding properties of the PH-PDZ supramodule of alpha-syntrophin. Embo J 24, 3985-3995.

48. Venkateswarlu, K., Oatey, P. B., Tavare, J. M., and Cullen, P. J. (1998) Insulindependent translocation of ARNO to the plasma membrane of adipocytes requires phosphatidylinositol 3-kinase. Curr Biol 8, 463-466. 
49. Varnai, P., Rother, K. I., and Balla, T. (1999) Phosphatidylinositol 3-kinase-dependent membrane association of the Bruton's tyrosine kinase pleckstrin homology domain visualized in single living cells. J Biol Chem 274, 10983-10989.

50. Campbell, R. E., Tour, O., Palmer, A. E., Steinbach, P. A., Baird, G. S., Zacharias, D. A., and Tsien, R. Y. (2002) A monomeric red fluorescent protein. Proc Natl Acad Sci U S A 99, 7877-7882.

51. Fivaz, M., and Meyer, T. (2003) Specific localization and timing in neuronal signal transduction mediated by protein-lipid interactions. Neuron 40, 319-330. 


\section{Legend to Table 1}

Protein modules used with fluorescent protein tags for visualization of specific phosphoinositides in single cells. FRET, fluorescence resonance energy transfer. 
Table 1

\begin{tabular}{|c|c|c|c|}
\hline Lipid & $\begin{array}{l}\text { Protein } \\
\text { module }\end{array}$ & Reference & Comment \\
\hline \multirow[t]{3}{*}{ Ptdlns3P } & $\begin{array}{l}\text { EEA1-(2x)- } \\
\text { FYVE }\end{array}$ & $(22-25)$ & $\begin{array}{l}\text { EEA1-GFP also binds phosphatidylserine and } \\
\text { phosphatidylinositol in vitro. The probe } \\
\text { interferes with early endosome formation. }\end{array}$ \\
\hline & Hrs-(2X)-FYVE & $(22,24,26)$ & \\
\hline & P40 $0^{\text {phox }}-\mathrm{PX}$ & $(27-30)$ & \\
\hline \multirow[t]{4}{*}{ Ptdlns4P } & OSBP-PH & $(31-33)$ & $\begin{array}{l}\text { Detects primarily the Golgi Ptdlns } 4 P \text { pool and } \\
\text { this binding also involves Arf1; binds also } \\
\text { Ptdlns }(4,5) P_{2} \text { in vitro. }\end{array}$ \\
\hline & FAPP1-PH & $(32-34)$ & See comment for OSBP-PH above. \\
\hline & $\mathrm{OSH} 2-\mathrm{PH}(2 \mathrm{x})$ & $(35,36)$ & $\begin{array}{l}\text { Detects PtdIns } 4 P \text { in the plasma membrane but } \\
\text { not in the Golgi compartment in mammalian } \\
\text { cells. }\end{array}$ \\
\hline & $\mathrm{OSH} 1-\mathrm{PH}$ & $(35,36)$ & $\begin{array}{l}\text { Localizes to the Golgi apparatus and plasma } \\
\text { membrane. }\end{array}$ \\
\hline Ptdlns5P & ING2-PHD & (37) & $\begin{array}{l}\text { Some binding to Ptdlns } 3 P \text { and Ptdlns } 4 P \text { in } \\
\text { vitro, but no colocalization with } 440^{\text {phox }}-\mathrm{PX} \text { in } \\
\text { vivo. }\end{array}$ \\
\hline \multirow[t]{2}{*}{ Ptdlns $(3,4) P_{2}$} & $\mathrm{p} 47^{\text {phox }}-\mathrm{PX}$ & $(27,38,39)$ & $\begin{array}{l}\text { Specificity has been questioned (39). A portion } \\
\text { of the domain binds anionic phospholipids, } \\
\text { such as phosphatidic acid or phosphatidyl- } \\
\text { serine; intramolecular association with the C- } \\
\text { terminal SH3 domain might mask membrane } \\
\text { interaction. }\end{array}$ \\
\hline & TAPP1-PH & $(40-42)$ & $\begin{array}{l}\text { Membrane penetration slows dissociation. A } \\
\text { mutant exists with less penetration and faster } \\
\text { dissociation kinetics ( } 41) \text {. }\end{array}$ \\
\hline \multirow[t]{2}{*}{ Ptdlns $(4,5) P_{2}$} & PLCס1-PH & $(2,3,43)$ & $\begin{array}{l}\text { PLCס1 contains the best characterized PH } \\
\text { domain, which binds strongly to both } \\
\text { Ptdlns }(4,5) P_{2} \text { and its isolated headgroup, D- } \\
\text { myo-inositol-1,4,5-trisphosphate. Does not } \\
\text { readily recognize Ptdlns }(4,5) P_{2} \text { in membranes } \\
\text { other than the plasma membrane. }\end{array}$ \\
\hline & Sla2-ANTH & $(44)$ & $\begin{array}{l}\text { Used to detect Ptdlns }(4,5) P_{2} \text { at sites of } \\
\text { endocytosis. }\end{array}$ \\
\hline Ptdlns $(3,5) P_{2}$ & Atg18 & $(40,45-47)$ & $\begin{array}{l}\text { May also bind Ptdlns } 3 P \text {. PH domains specific } \\
\text { for Ptdlns }(3,5) P_{2} \text { in vitro have been identified } \\
\text { (Centaurin- } \beta 2 \text { and } \alpha \text {-Syntrophin), but not yet } \\
\text { utilized as molecular probes. }\end{array}$ \\
\hline \multirow[t]{4}{*}{ Ptdlns $(3,4,5) P_{3}$} & Akt-PH & $(10,11,41)$ & $\begin{array}{l}\text { Binds also to Ptdlns }(3,4) P_{2} \text {. Has been used in } \\
\text { FRET-based biosensor }(21) \text {. }\end{array}$ \\
\hline & GRP1-PH & $(10,41)$ & $\begin{array}{l}\text { Binds to PtdIns }(3,4) P_{2} \text { with much lower affinity. } \\
\text { Has been used in FRET-based biosensor }(20)\end{array}$ \\
\hline & ARNO-PH & $(41,48)$ & $\begin{array}{l}\text { Low affinity for Ptdlns }(3,4,5) P_{3} \text {. Binds also } \\
\text { Ptdlns }(3,4) P_{2} \text {. }\end{array}$ \\
\hline & Btk-PH & $(41,49)$ & Specific for Ptdlns $(3,4,5) P_{3}$ \\
\hline
\end{tabular}




\section{Figure legends}

Figure 1. Confocal and total internal reflection fluorescence (TIRF) microscopy images of the distribution of GFP-tagged PH-domains in insulin-secreting MIN6-cells. (A) The

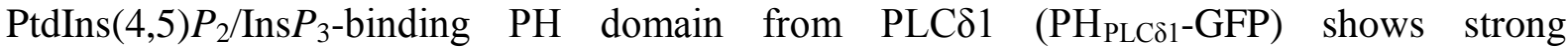
localization to the plasma membrane under basal conditions, but translocates to the cytoplasm after activation of phospholipase $\mathrm{C}$ with $100 \mu \mathrm{M}$ of the muscarinic agonist carbachol. The loss of GFP from the membrane is seen as decreased fluorescence in the TIRF image. (B) The GFP-tagged PtdIns $(3,4) P_{2} /$ PtdIns $(3,4,5) P_{3}$-binding PH domain from Akt $\left(\right.$ GFP-PH $\left.\mathrm{Akt}_{\mathrm{At}}\right)$ shows cytoplasmic and nuclear distribution in unstimulated cells, but translocates to the plasma membrane after activation of PI3-kinase with $100 \mathrm{nM}$ insulin. The accumulation of GFP at the plasma membrane is seen as increased fluorescence in the TIRF image. Scale bars, $5 \mu \mathrm{m}$. (C) The principle of TIRF microscopy. An exponentially decaying electromagnetic field ("evanescent wave") is generated by the total internal reflection of the laser excitation light at the top surface of the coverslip. This field excites fluorescent molecules within $\sim 100 \mathrm{~nm}$ above the glass, corresponding to the plasma membrane and immediate sub-membrane space. The fluorescence intensity correlates with the degree of membrane localization of the fluorescent protein construct. (D) Large area evanescent wave illumination of MIN6 cells expressing GFP-tagged GRP1 with fluorescence imaging through a 10x objective. Scale bar, $200 \mu \mathrm{m}$.

Figure 2. Single and dual wavelength time-lapse TIRF microscopy recordings of PI biosensor membrane localization in individual MIN6 cells. (A) Activation of phospholipase C with the muscarinic receptor agonist carbachol results in dissociation of $\mathrm{PH}_{\mathrm{PLC} \delta 1}-\mathrm{GFP}$ from the plasma 
membrane with concomitant loss of fluorescence that is reversed when the stimulus is removed. The biphasic response with a strong initial response followed by a sustained plateau has been found to result from distinct mechanisms of $\mathrm{Ca}^{2+}$ feedback on phospholipase $\mathrm{C}$ (17). (B) Elevation of the glucose concentration from 3 to $11 \mathrm{mM}$ triggers oscillations in the membrane concentration of PtdIns(3,4,5) $P_{3}$ as recorded with GFP-tagged GRP1 (black trace). These changes are not due to alterations of cell shape or adhesion, since simultaneous measurements of the red fluorescent protein tdimer2 (50) anchored to the membrane with a polybasic sequence and a C-terminal prenylation motif (51) show a stable signal (grey trace). The glucose-induced PtdIns $(3,4,5) P_{3}$ oscillations have been found to reflect pulsatile release of insulin, resulting in autocrine stimulation of insulin receptors and intermittent activation of PI3-kinase (19). GFP-GRP1 and membrane-anchored tdimer2 were co-expressed in the same cell. GFP was excited at $488 \mathrm{~nm}$ and tdimer2 at $514 \mathrm{~nm}$ using an argon ion laser. Emission was measured at 525/40 $\mathrm{nm}$ for GFP and $630 \mathrm{~nm}$ long pass for tdimer2.

Figure 3. Simultaneous TIRF microscopy recordings of membrane $\operatorname{PtdIns}(3,4) P_{2} /$ PtdIns $(3,4,5) P_{3}$ concentration with GFP- $\mathrm{PH}_{\mathrm{Akt}}$ and the sub-membrane cytoplasmic $\mathrm{Ca}^{2+}$ concentration with Fura Red in a single insulin-secreting MIN6 cell. Depolarization of the plasma membrane by raising the $\mathrm{KCl}$ concentration to $30 \mathrm{mM}$ results in voltage-dependent $\mathrm{Ca}^{2+}$ influx and elevation of the cytoplasmic $\mathrm{Ca}^{2+}$ concentration. Increase of $\mathrm{Ca}^{2+}$ is associated with loss of Fura Red fluorescence (grey trace), but the trace has been inverted to show the increase in $\mathrm{Ca}^{2+}$ as an upward deflection of the curve. It is apparent that the increase in $\mathrm{Ca}^{2+}$ precedes that of GFP-PH $\mathrm{PH}_{\mathrm{Akt}}$ fluorescence, which is due to $\mathrm{Ca}^{2+}$ triggering the exocytosis of insulin, which subsequently activates insulin receptors and PI3-kinase via autocrine feedback. 
FIGURE 1

A

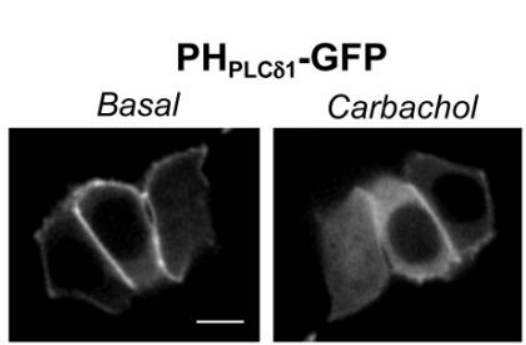

B
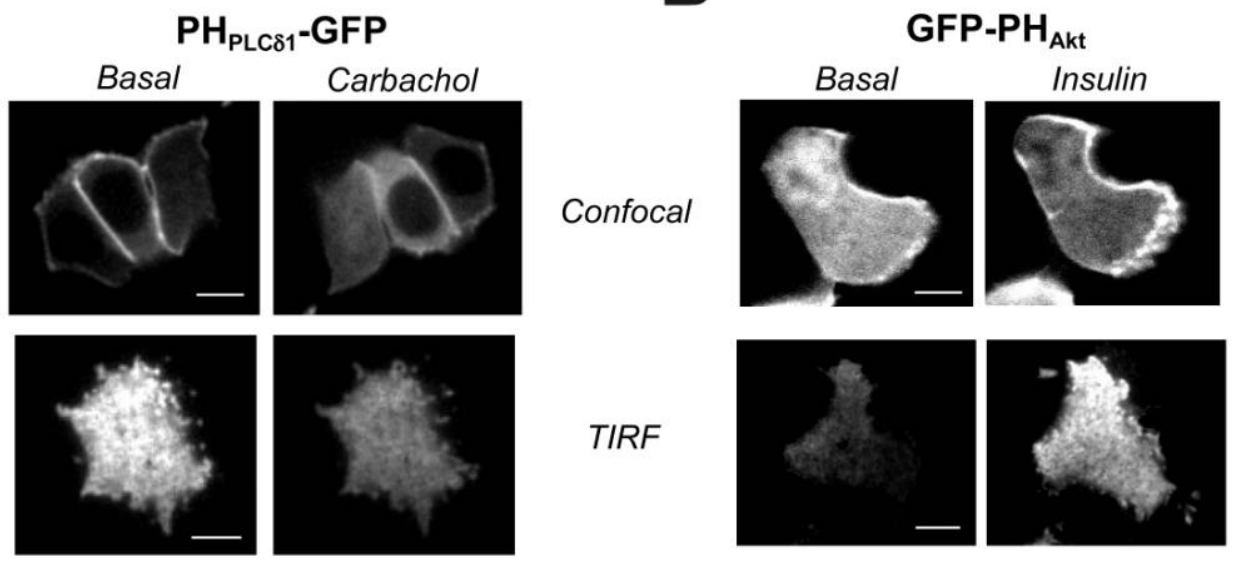

C

\section{TIRF microscopy}

Biosensor in cytoplasm

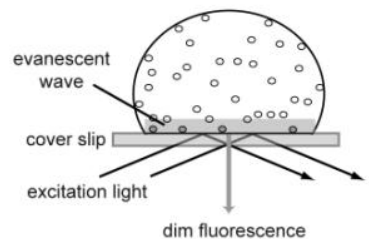

Biosensor at plasma membrane

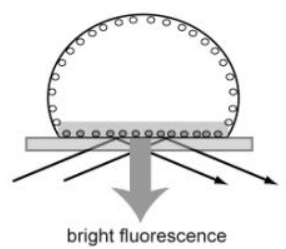

D TIRF imaging with $10 x$ objective

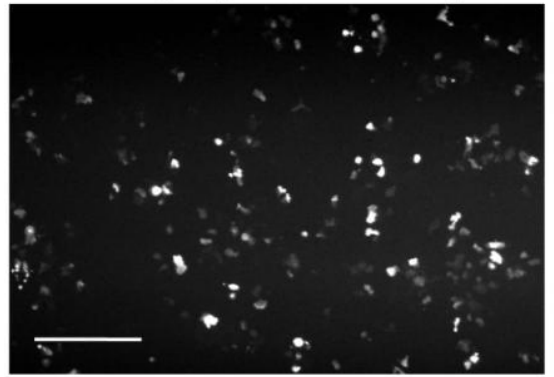


FIGURE 2

A

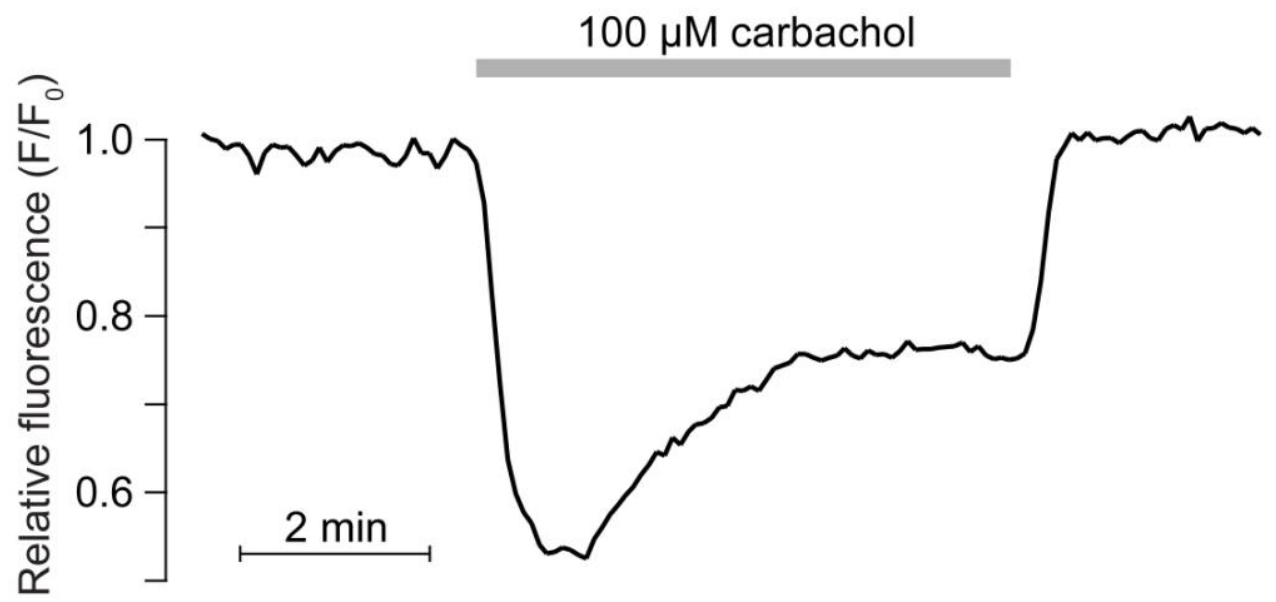

B

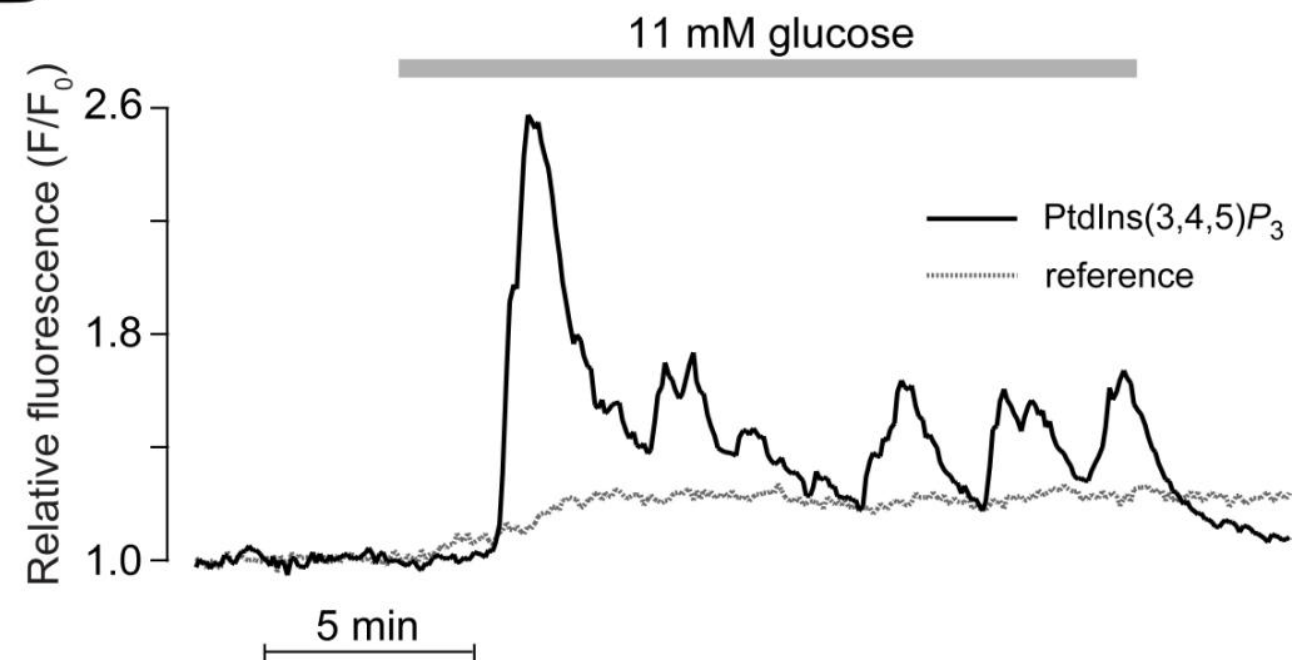


FIGURE 3

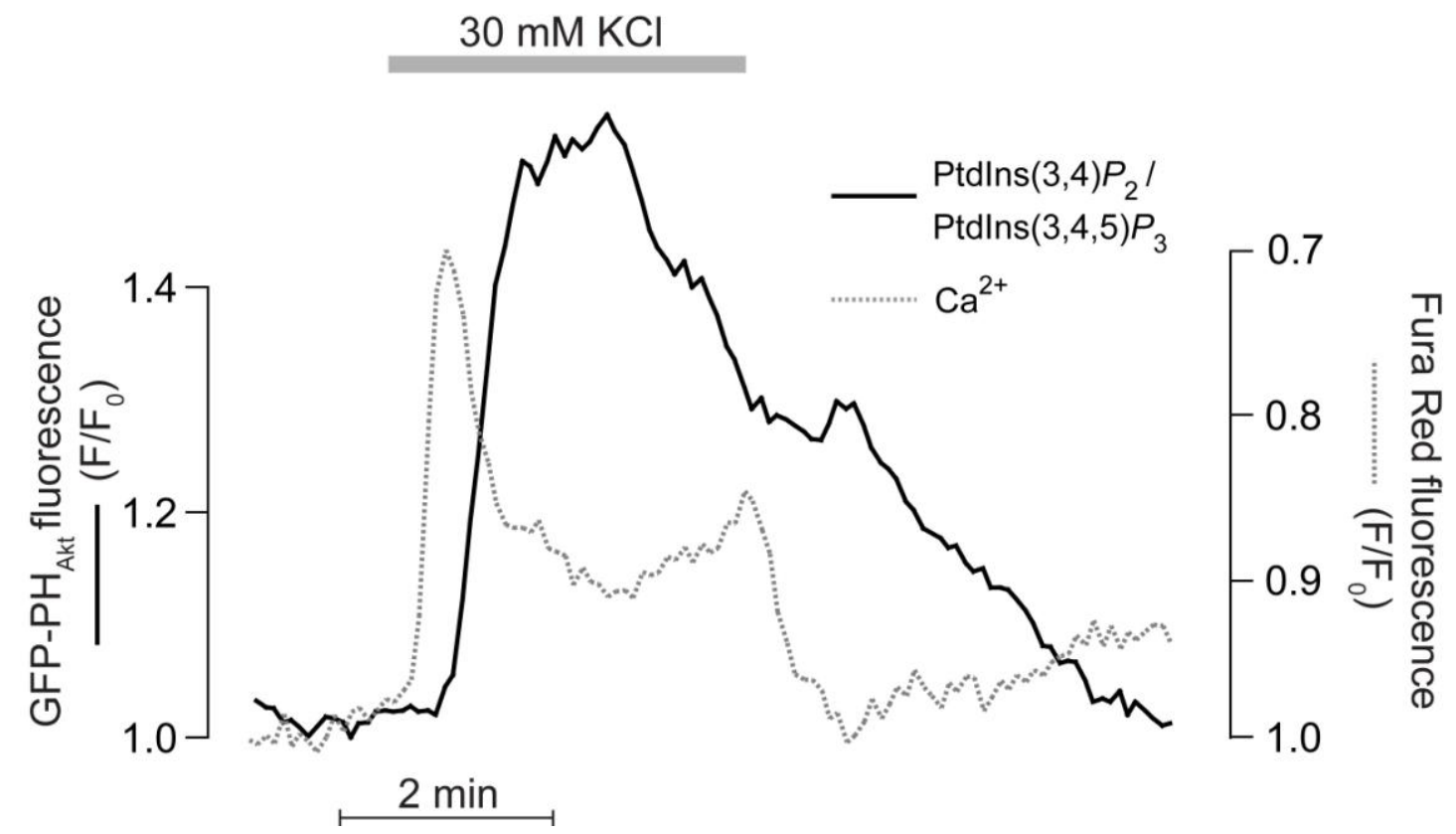

